\title{
Corneal endothelial cell density in twins
}

\author{
N. C. PRICE AND D. J. BARBOUR
}

From the Eye Hospital, Oxford

SUMmARY Corneal endothelial cell density was measured in normal subjects and in a group of monozygotic and dizygotic twins. Cell density was found to decline with age and to be similar in right and left eyes in normal subjects. Both monozygotic and dizygotic twins were found to have very similar mean endothelial cell densities and particularly so in like-sided eyes.

Corneal endothelial cell density estimations for normal subjects have been previously reported by several authors. ${ }^{1-5}$ Although it is known that some endothelial dystrophies have a genetic component, ${ }^{67}$ no studies have been reported in which the familial inheritance of endothelial cell density in normal persons has been examined.

The purpose of this paper is to report a study to determine endothelial cell densities in a group of mono- and dizygotic twins and to compare these with a large normal population.

\section{Materials and methods}

Axial endothelial photographs were taken of 285 eyes after it had been established they had no ocular pathology other than senile cataract. Included in this series are 32 eyes from 8 pairs of dizygotic twins and 28 eyes from 7 pairs of monozygotic twins.

Correspondence to Dr N. C. Price. Cataract Management Study. Eve Hospital. Walton Street. Oxford OX2 6AN.
All photographs were taken with a Nikon noncontact endothelial camera. The films were processed and prints made as previously described, and cell density estimated by fixed frame analysis of 3 prints for each eye. ${ }^{8}$ The area of cells counted was equivalent to an endothelial area of between $0.025 \mathrm{~mm}^{2}$ and 0.20 $\mathrm{mm}^{2}$ in each photograph (Fig. 1).

All cell density estimations were performed by one of the authors. For a group of 9 prints counted on 3 separate occasions in a 'blind' manner the coefficient of variation in estimated cell density for prints of a high standard was found to be $2 \cdot 1 \%$.

\section{Results}

Endothelial cell density was found to decrease significantly with age (Fig. 2), although as previously reported there is a wide range of densities for any given age.

For 58 eyes photography was repeated after one month, and a high degree of correlation was found

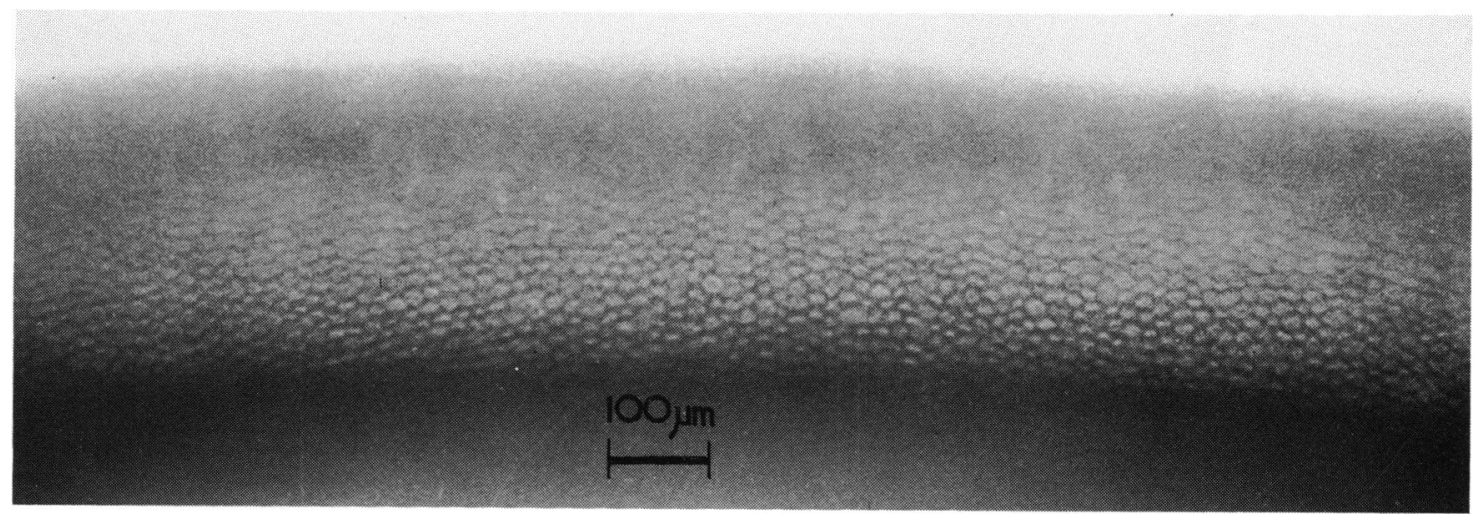

Fig. 1 Endothelial photograph to show field of Nikon endothelial camera. 


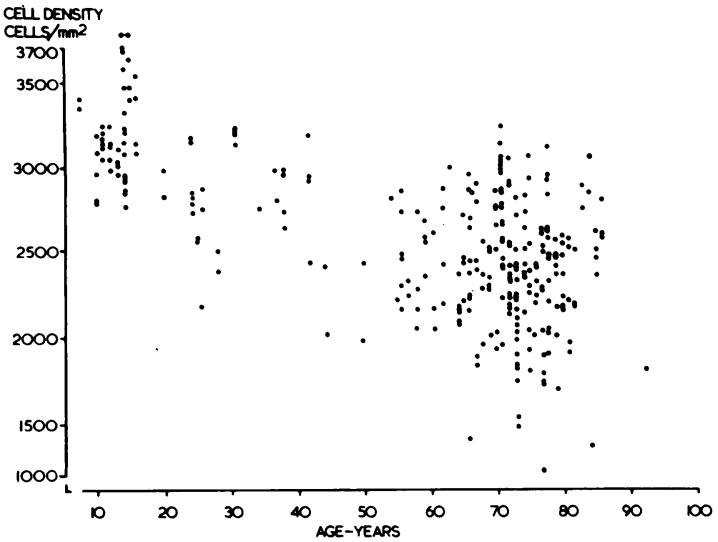

Fig. 2 Endothelial cell density vs. age: normal subjects.

between the estimated cell density on the 2 occasions $(r=0.91)$ (Fig. 3$)$. In a group of 83 patients cell density was compared for the 2 eyes (Fig. 4), and a high degree of correlation between the 2 eyes was found $(\mathrm{r}=0.92)$.

The twins, as expected, showed a similar high degree of correlation when their 2 eyes were compared $(\mathrm{r}$ monozygotic $=0.91, \mathrm{r}$ all $=0.89)($ Table 1$)$.

When mean cell density for the 2 eyes of a twin was compared with the mean cell density of the other twin, the 7 pairs of monozygotic twins showed an even higher correlation coefficient $(r=0.93)$, while that for the whole population remained unchanged $(r=0 \cdot 89)$ (Fig. 5). A comparison of cell densities between eyes of the same side (i.e., R:R or L:L) in

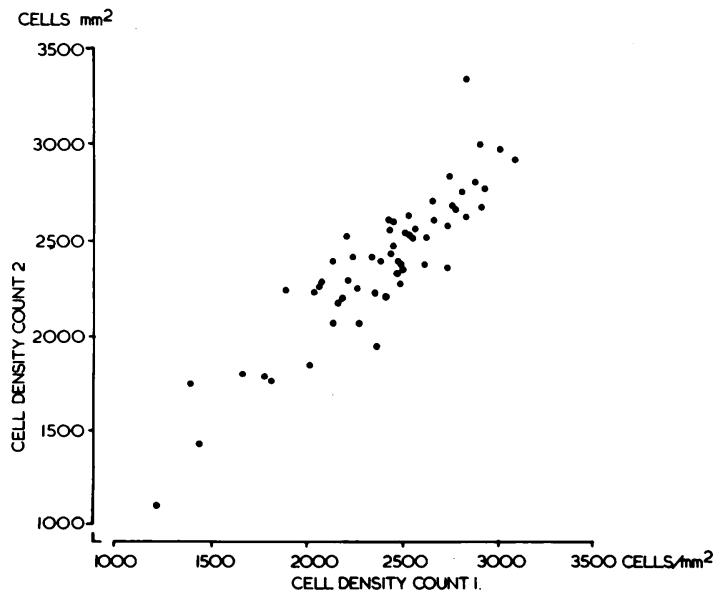

Fig. 3 Endothelial cell density calculated on 2 visits at least 30 days apart.
Table 1 Endothelial cell density in twins

\begin{tabular}{|c|c|c|c|c|c|c|c|}
\hline \multicolumn{4}{|c|}{ 1. Monozygotic } & \multicolumn{4}{|c|}{ 2. Dizugotic } \\
\hline \multirow{2}{*}{$\begin{array}{l}\text { Case } \\
\text { no. }\end{array}$} & \multirow[t]{2}{*}{ Age } & \multicolumn{2}{|c|}{ Cell density } & \multirow{2}{*}{$\begin{array}{l}\text { Case } \\
\text { no. }\end{array}$} & \multirow[t]{2}{*}{ Age } & \multicolumn{2}{|c|}{ Cell densitv } \\
\hline & & Right & Left & & & Right & Left \\
\hline $1 \mathrm{~A}$ & 11 & 2799 & 3089 & $8 \mathrm{~A}$ & 12 & 3222 & 3140 \\
\hline 1B & & 2962 & 3184 & $8 \mathrm{~B}$ & & 3133 & 2978 \\
\hline $2 \mathrm{~A}$ & 11 & 3120 & 3147 & $9 \mathrm{~A}$ & 12 & 3300 & 3040 \\
\hline 2B & & 3037 & 3187 & 9B & & 3226 & 3140 \\
\hline $3 \mathrm{~A}$ & 13 & 2913 & 3115 & $10 \mathrm{~A}$ & 14 & 3234 & 3467 \\
\hline 3B & & 3067 & 3002 & $10 \mathrm{~B}$ & & 3317 & 3203 \\
\hline $4 \mathrm{~A}$ & 14 & 2827 & 2782 & $11 \mathrm{~A}$ & 14 & 3076 & 3137 \\
\hline 4B & & 2848 & 2929 & $11 \mathrm{~B}$ & & 2902 & 2913 \\
\hline $5 \mathrm{~A}$ & 14 & 3756 & 3573 & $12 \mathrm{~A}$ & 15 & 3468 & 3400 \\
\hline $5 B$ & & 3657 & 3687 & $12 \mathrm{~B}$ & & 3769 & 3640 \\
\hline $6 \mathrm{~A}$ & 31 & 3107 & 3196 & $13 \mathrm{~A}$ & 16 & 3134 & 3396 \\
\hline $6 \mathrm{~B}$ & & 3200 & 3194 & 13B & & 3089 & 3548 \\
\hline $7 \mathrm{~A}$ & 72 & 3000 & 2647 & $14 \mathrm{~A}$ & 26 & 2784 & 2807 \\
\hline \multirow[t]{3}{*}{ 7B } & & 2760 & 2400 & 14B & & 3142 & 3154 \\
\hline & & & & $15 \mathrm{~A}$ & 76 & 2247 & 2400 \\
\hline & & & & $15 \mathrm{~B}$ & & 2320 & 2420 \\
\hline
\end{tabular}

twins showed correlation coefficients of 0.90 for monozygotic twins and 0.91 for the whole twin population.

The cell densities of 'opposite' eyes within a pair of twins showed a correlation coefficient of 0.77 whether mono- or dizygotic.

\section{Discussion}

The close correlation achieved on repeated axial photography suggests an accuracy in photographic method comparable with that of Olsen. ${ }^{5}$ The coefficient of variation is similar to that quoted by Waring et al. ${ }^{9}$

Endothelial cell density falls by 30 to $50 \%$ between the ages of 20 and 80 , and there is no statistical

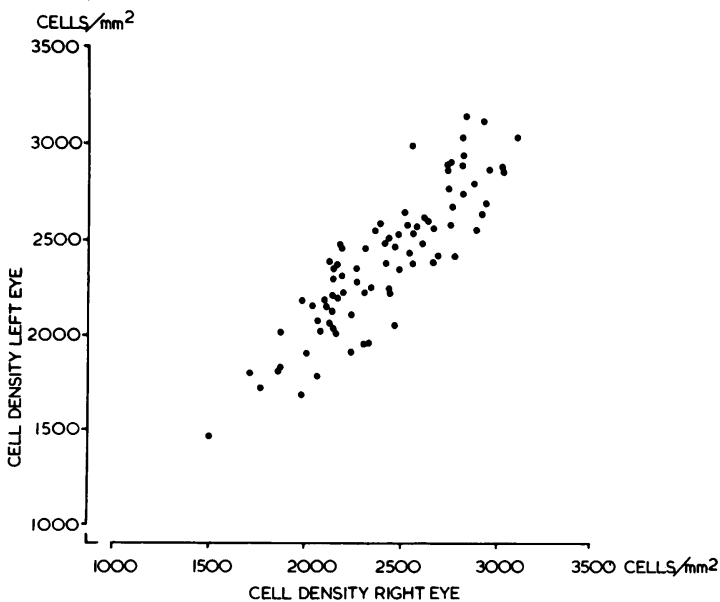

Fig. 4 Endothelial cell density $R$ vs. $L$ eyes. 


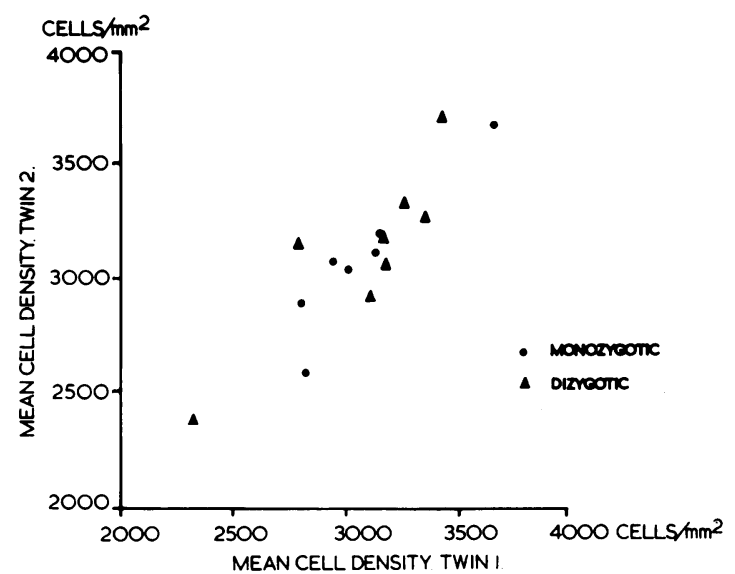

Fig. 5 Mean endothelial cell density of both eyes, twin $1 \mathrm{vs}$. twin 2.

difference between the sexes. In normal patients the cell density of the 2 eyes is also similar. ${ }^{1-5}$

From our results it appears that both monozygotic and dizygotic twins have virtually identical endothelial cell densities, the correlation being particularly close between like-sided eyes. While it is true that most of our twins were young ( 11 out of 15 pairs were less than 20 years old) and may be expected to show high cell density and therefore close correlation, the results remain significant when it is remembered that we found a variation in cell density of about $30 \%$ within the 16 eyes of 14 -year-olds examined.

The 4 pairs of twins over 20 years of age also showed a close correlation between like-sided eyes $(r=0.99)$, suggesting that in the absence of ocular pathology the endothelial cell densities of twins decline at the same rate with age.

Such close correlation between endothelial cell densities in twins may be due to genetic factors or to environmental influences in utero. A study of siblings of closely related ages would be necessary to identify the relative importance of these influences.

This work was supported by National Institutes of Health Grant no. EYO 2677-02.

Thanks are due to $\mathrm{Mr} \mathrm{H}$. Cheng and $\mathrm{Mr} \mathrm{A}$. J. Bron for support and encouragement and to Mrs M. Platts for secretarial help.

\section{References}

1 Bourne WM. Kaufman HE. Specular microscopy of human corneal endothelium in vivo. Am J Ophthalmol 1976;81: 319-23.

2 Laing RA, Sandstrom MM, Berrospi AR, Leibowitz HM. Changes in the corneal endothelium as a function of age Exp Eve Res 1976; 22: 587-94.

3 Sturrock GD. Sherrard ES. Rice NSC. Specular microscopy of the corneal endothelium. Br J Ophthalmol 1978; 62: 809-14.

4 Laule A. Cable MK. Hoffman CE. Hanna C. Endothelial cell population changes of human cornea during life. Arch Ophthalmol 1978; 96: 2031-5.

5 Olsen T. Non-contact specular microscopy of the human corneal endothelium. Acta Ophthalmol (Kbh) 1979; 51: 986-98.

6 Krachmer JH, Purcell JJ, Young CW, Bucher KD. Corneal endothelial dystrophy. Arch Ophthalmol 1978; 96: 2036-9.

7 Waring GO, Rodrigues MM. Laibson PR. Corneal dystrophies. II endothelial dystrophies. Surv Ophthalmol 1978; 23: 147-68.

8 Price NC. Cheng H. Contact and non-contact specular microscopy. Br J Ophthalmol 1981; 65: 568-74.

9 Waring GO, Krohn MA. Ford SE, Harris RR, Rosenblatt LS. Four methods of measuring human corneal endothelial cells from specular photomicrographs. Arch Ophthalmol 1980: 98: 848-55. 